\title{
A Transit-Oriented Development Concept Model to Reduce Traffic Congestion in Urban Area
}

\author{
Muhammad Andika Satrugna Mahardhika, Erma Suryani and Alifiansyah Arrizqi Hidayat \\ Department of Information Systems, Institut Teknologi Sepuluh Nopember, Surabaya \\ e-mail: erma.suryani@gmail.com
}

\begin{abstract}
Traffic congestion have caused many impacts and losses both in terms of transportation, but also in terms of environmental, economic and social aspects. The increasing number of private vehicles and the decline in public interest in using public transportation is one of the main factors. The decline in public interest in using public transportation is influenced by several reasons, such as ease of access, lack of modes of transportation available, the duration of waiting time, and the duration of travel time. The TOD concept is used because it is a combination of urban planning development and transportation system design, which can help to solve transportation problems especially in urban areas. This study aims to identify and examine how TOD can increase the use of transit modes and transportation efficiency. This study used the System Dynamics model as a means of conceptual modeling (Causal Loop Diagrams) which will describe in detail the factors that will encourage the use of transit modes and improve the efficiency of the transportation system. The results of this study are expected to help provide an overview for policy makers or related parties in determining future directions and strategies related to the existing urban transportation system.
\end{abstract}

Keywords-System Dynamics, Traffic Congestion, TransitOriented Development, Transportation System.

\section{INTRODUCTION}

C ONGESTION is shown by the value of the traffic density which describes a measure of how crowded or how much traffic flows per kilometer. In other words, it is the ratio of the number of vehicles passing per total road area [1]. Traffic congestion are common situation in most of major cities in the world. But it will get worse if it causes huge impacts and losses. The impact caused by traffic congestion not only affects the transportation aspect, but also the environmental, economic and social aspects. In 2003 alone recorded losses caused by congestion in Indonesia reached US \$ 634 million [2].

The increasing number of private vehicles and the decrease of public interest in using public transportation are also one of the factors causing traffic congestion. The current transportation conditions also still less productive because people are still used to travel by private vehicles rather than using public transportation. In Indonesia today it is very easy to get or buy private vehicles, especially motorcycle, the costs of those vehicle are far cheaper compared to the other countries. This has become one of the factors driving people to prefer private vehicles [3].

The decrease of public interest in using public transportation is influenced by several reasons, including limited transportation facilities and infrastructure, lack of

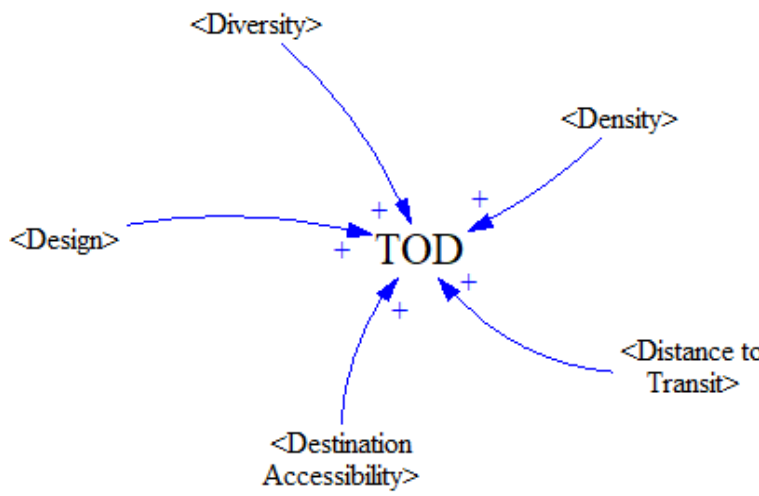

Figure 1. Transit-Oriented Development Model

modes of transportation, duration of waiting time, and duration of travel time [3], [4]. Even though increasing the use of public vehicles has positive impacts such as reducing fuel consumption, road space usage, and vehicle operating costs [5]. Therefore, we need a solution that can increase the attractiveness of using public modes so that people can switch from private vehicles to public transport.

The concept of Transit Oriented Development (TOD) combines the concept of urban planning development with the transportation system. The focus is to concentrate the development around the transit station [6]. The development of the area must also have a variety of types of land use whose purpose is to create land use patterns that can facilitate the choice of diverse modes of transportation, especially to support the use of public transportation and the use of nonmotorized transportation, which will reduce the level of use of private vehicles so as to reduce the level of traffic density [7], [8].

The main purpose of TOD is to increase the use of public and non-machine transportation such as biking or walking. In addition to reducing the amount of use of private vehicles. Reducing the number of public transportations uses and increasing the use of public transportation can potentially reduce the level of congestion [7], [8].

\section{METHODS}

This study uses system dynamics modeling because the system dynamics simulation approach is considered suitable for overcoming problems that all components have an interrelation or interaction between one another, because it is based on a loop or feedback process in a part of the system [9], [10]. 
The $6^{\text {th }}$ International Seminar on Science and Technology (ISST) 2020

July $25^{\text {th }} 2020$, Institut Teknologi Sepuluh Nopember, Surabaya, Indonesia
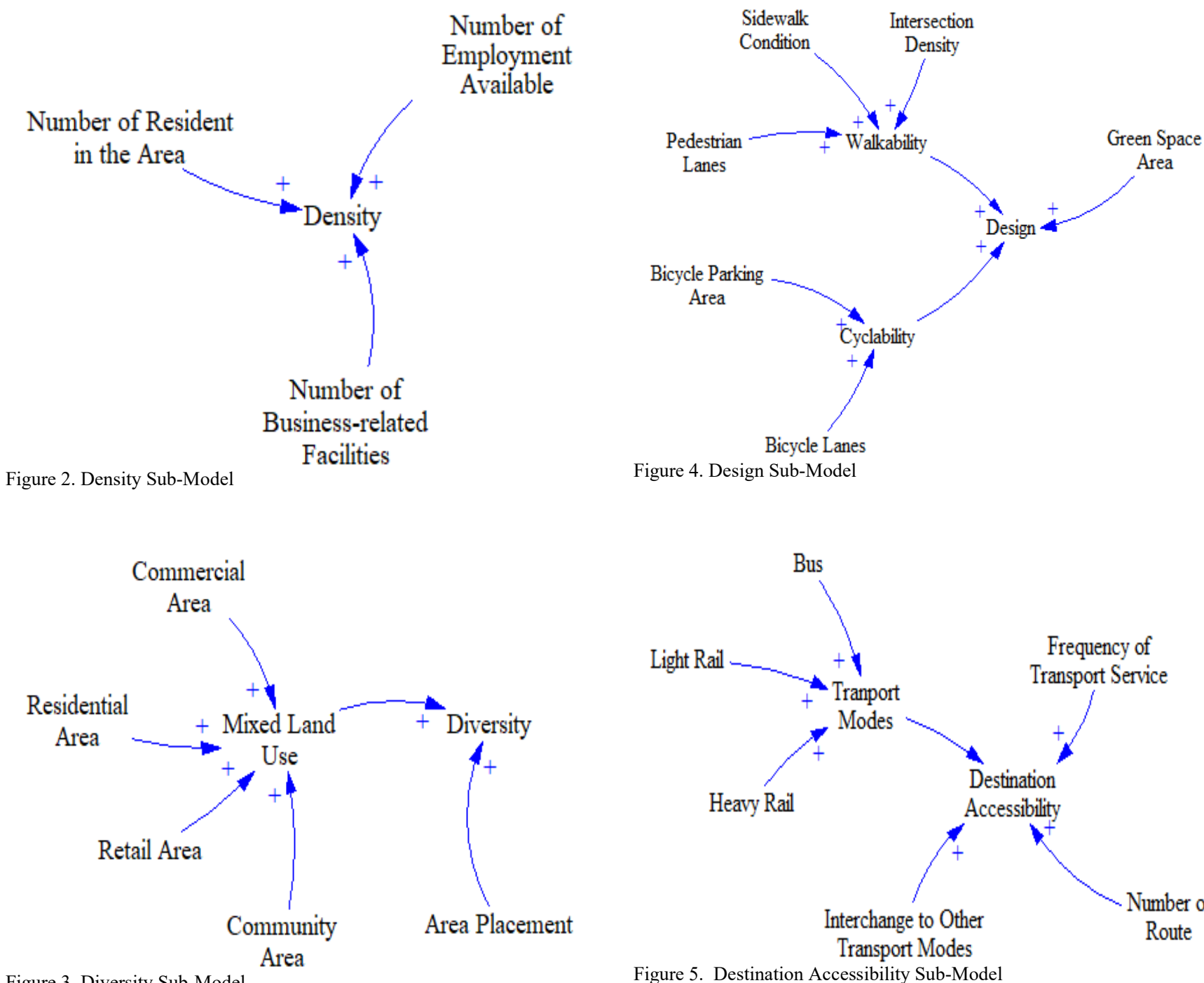

Figure 3. Diversity Sub-Model

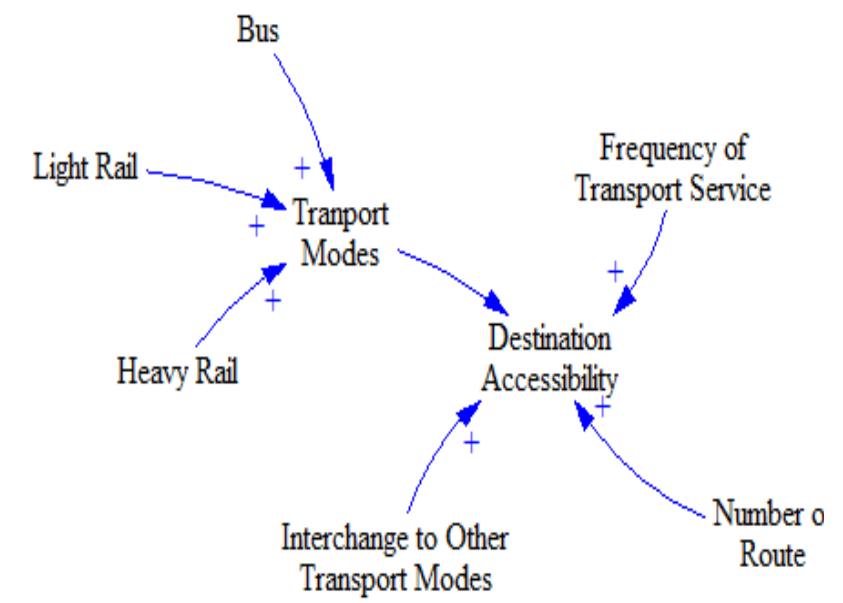

Figure 5. Destination Accessibility Sub-Model

\section{A. System Dynamics}

System dynamic is a method for solving a problem of a complex systems, which allow us to see dynamic interaction between factors that exist in the systems. There are five stages carried out to develop a model including Problem Articulation and Dynamic Hypothesis [10].

\section{B. Problem Articulation}

On this stage, a problem will be defined to be used as a research topic. Then, we analyze and identified each variable from identified problem. Data and information collection also carried out in this stage. Where those were obtained through literature studies, observations, and interviews from relevant source such as credible journals or papers, government agencies such as the Department of Transportation and Central Bureau of Statistics, and several credible sources such as website article and mass media.

\section{Dynamic Hypothesis}

At this stage, modelling is started by forming a causal loop diagram. Causal loop diagram contains connection between each variable that has been previously defined to form a feedback cycle. Each relationship describe causality between those variables. Each relationship also has a polarity both positive (+) and negative (-) to illustrate how those

relationship between these variables affect each other. In addition, feedback in causal loop diagram has two types, reinforcing loop that illustrates the reinforcement of a cycle, and balancing loop where illustrates the stability of a cycle.

\section{RESULTS AND DISCUSSION}

This section will discuss the result and discussion of the model, sub model, and all factors that involved in it, including internal and external factors. Discussion in this section will focuses on the result of literature studies obtained from various journal, papers, book, and other source relevant to the topics discussed, namely regarding Transit-Oriented Development and Urban Transportation System. Here is the result of studies:

\section{A. Boundary Adequacy}

Internal and external factors, both significant and auxiliary variable that influence each other in the model are listed in Table 1.

\section{B. Transit-Oriented Development Model}

Transit Oriented Development concept is intended to centralize city development around the transit station. Development of the area must have a variety of types land use, such as land for housing, office, shop, and activity center. 
The $6^{\text {th }}$ International Seminar on Science and Technology (ISST) 2020

July $25^{\text {th }} 2020$, Institut Teknologi Sepuluh Nopember, Surabaya, Indonesia

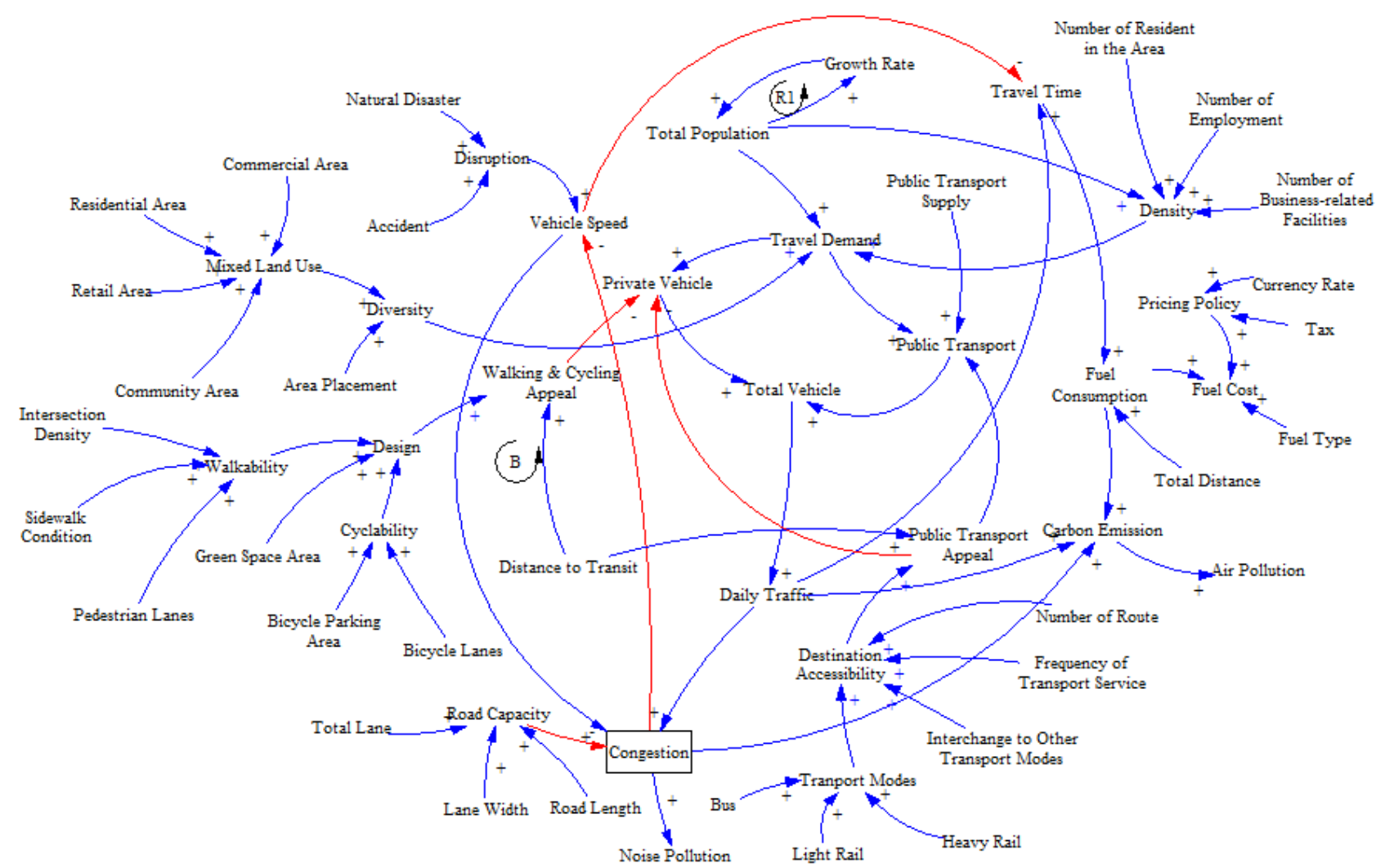

Figure 6. Causal Loop Diagram of Transit-Oriented Development for Urban Transportation Systems

The aim of this concept to create land use patterns that can facilitate the choice of diverse modes of transportation, especially to support the use of public transportation and the use of non-motorized transportation [6]. There are five special characteristics of Transit Oriented Development (TOD), namely Density, Diversity, Design, Destination Accessibility, and Distance to Transit [11], [12]. The model of Transit-Oriented Development can be seen in Figure 1.

\section{Density Sub-Model}

Density shows residential density, commercial density, and employment density that will have the potential for commuting behavior in the TOD area. Density is divided into two-part, low density (less than 30 inhabitants/hectare) and high density (more than 30 inhabitants/hectare) [6], [13]. In TOD area itself it is recommended to have at least 10 inhabitants/hectare to stimulate growth of transit passenger in the area. Characteristic of low density will result in a high dependency to use private vehicles which will have an impact on the high number of congestion and reduced accessibility [14]. While high density allows to increase investment in transit modes, which have an impact on increasing the accessibility and use of public transportation, high density also help encourage the economic growth [15]. Factors that affecting the value of density can be seen in Figure 2, those are number of people who live in the TOD area, number of jobs available around the area, and number of business facilities available. These three factors will become a positive stimulus to increase the value of density.

\section{Diversity Sub-Model}

Diversity shows the diverse of land type used in a TOD area. Diversity is important because it is one of the factors to encourage the development of TOD area itself. There are several types of areas or facilities that must be present, including residential area, retail or shopping areas, and community areas or public facilities [16]. Placement of each area is also an important factor to support the level of diversity. Factors that affect diversity can be seen in Figure 3.

\section{E. Design Sub-Model}

Design here is specific to the state of artificial environment associated with pedestrian and cyclist. For TOD area its highly recommended to have a sidewalk that is friendly and safe for pedestrians [17]. Sidewalk environmental conditions must also be considered to provide comfort for pedestrians. In addition, existence of special facilities such as green open spaces as well as lanes and special parking lot for cyclist will be an added value if presented side by side with the sidewalk. These things are intended to encourage people who live nearby to be able to travel without a private vehicle to work or other places, as to reduce the amount of private vehicle uses. The sub-model of design can be seen in Figure 4.

\section{F. Destination Accessibility Sub-Model}

Destination accessibility shows how easy it is to get access from their place of residence to other places in the vicinity and places outside their area [12]. This characteristic is also related to the number and modes of transportation that exist in TOD area. These modes of transportation consist of shortdistance modes such as Light Rail (LRT), as well longdistance modes such as Heavy Rail (MRT) [3]. Another influential factor is how to access or exchange between the other types of transportation modes. In addition, frequency of how often the modes of transportation operates is also a factor to increase the value of accessibility [18]. These factors can be seen in Figure 5. 
The $6^{\text {th }}$ International Seminar on Science and Technology (ISST) 2020

July $25^{\text {th }} 2020$, Institut Teknologi Sepuluh Nopember, Surabaya, Indonesia

Table 1.

Boundary adequacy of Urban Transportation Systems

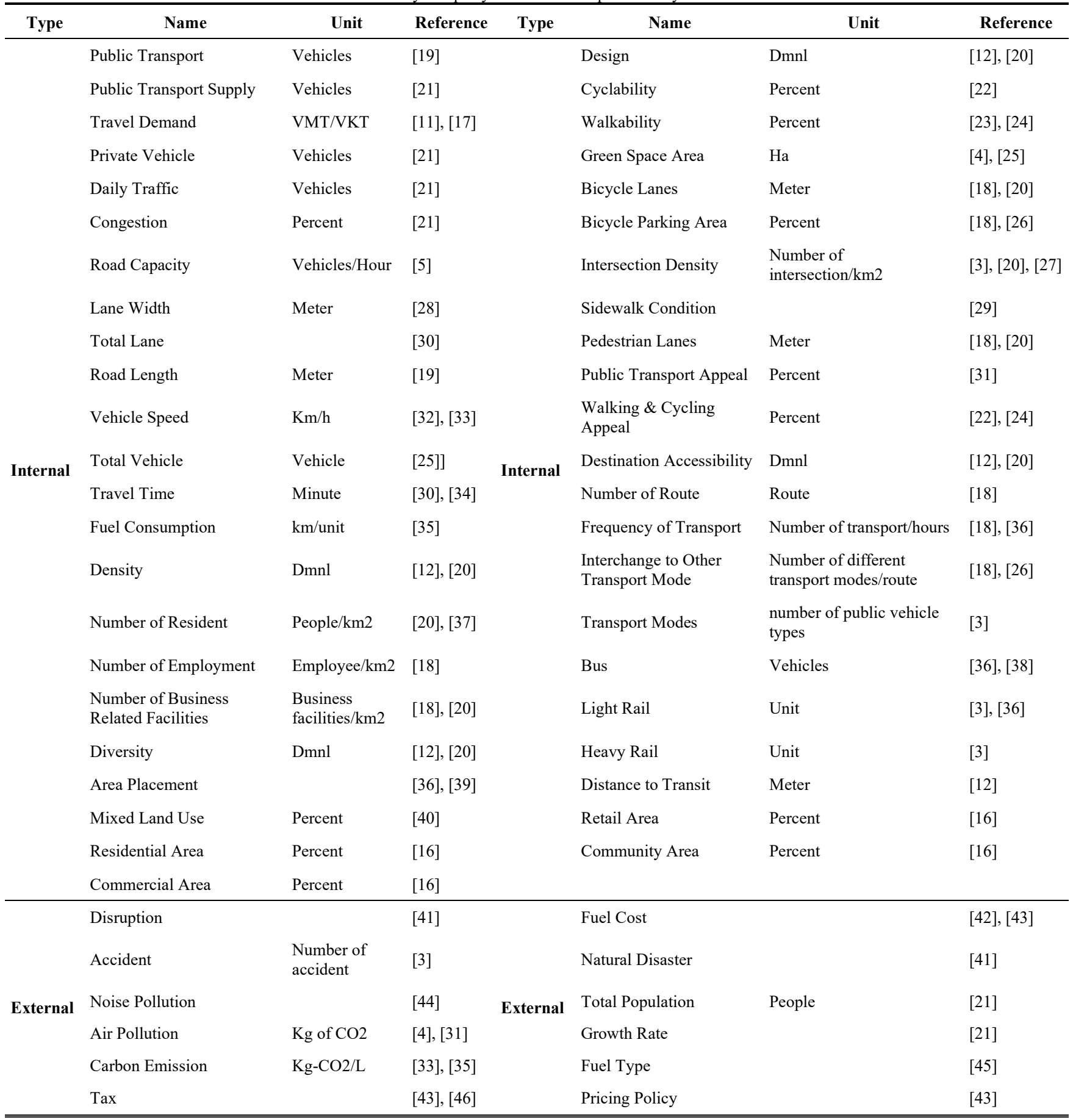

G. Urban Transportation System Model with the TOD Concept

Figure 6 shows a combination of all previous TOD sub model that are combined with sub model of the urban transportation system. In Figure 6 describes overall variables, causal relationships, and feedback of each variable.

\section{CONCLUSIONS}

Based on the results of analysis and discussion carried out in this study, it can be concluded:

1. Result of analysis on the TOD concept model in transportation system produce some important information regarding several variable that have a relation to the level of congestion, namely road capacity, vehicle speed, daily traffic, carbon emission, noise pollution.

2. Five of TOD sub models are not directly related to level of congestion, but instead are directly related to travel demand, private vehicle and public transportation. From the polarity can be concluded that if the application of TOD concept is right, it will be able to increase travel demand for public vehicles and can reduce number of private vehicles uses, which will have an impact on reducing the level of congestion. These results are consistent with what was stated in [7] and [8]. 
The $6^{\text {th }}$ International Seminar on Science and Technology (ISST) 2020

July $25^{\text {th }}$ 2020, Institut Teknologi Sepuluh Nopember, Surabaya, Indonesia

3. From causal loop diagram, further research can be done by developing several scenarios to predict the condition of the transportation system to resolve the traffic congestion in urban area.

\section{ACKNOWLEDGMENTS}

This research was supported by the Department of Information Systems, Institut Teknologi Sepuluh Nopember (ITS) Surabaya. We would like to thank Erma Suryani, S.T., M.T., Ph.D., which takes an important part in the research process.

\section{REFERENCES}

[1] F. A. Pinagara and S. Khamtanet, "Will Jakarta Still Have Traffic Congestion after MRT?," in Proceedings of the International Conference on Business and Management Research (ICBMR 2017), 2017, pp. 311-321, doi: 10.2991/icbmr-17.2017.29.

[2] F. Steinberg, "Jakarta: Environmental problems and sustainability," Habitat Int., vol. 31, no. 3-4, pp. 354-365, 2007, doi: 10.1016/j.habitatint.2007.06.002.

[3] S. Soehodho, "Public transportation development and traffic accident prevention in Indonesia," IATSS Res., vol. 40, no. 2, pp. 76-80, 2017, doi: 10.1016/j.iatssr.2016.05.001.

[4] H. S. Hasibuan, T. P. Soemardi, R. Koestoer, and S. Moersidik, "The role of Transit Oriented Development in constructing urban environment sustainability, the case of Jabodetabek, Indonesia," Procedia Environ. Sci., vol. 20, pp. 622-631, 2014, doi: 10.1016/j.proenv.2014.03.075.

[5] M. W. Zulfikar, H. Kusnoputranto, B. Tjahjati, and B. Darmadi, "Model restrictions on the use of motor vehicles to reduce congestion and air pollution in order to achieve sustainable city in Jakarta," Aust. J. Basic Appl. Sci., vol. 7, no. 6, pp. 537-542, 2013.

[6] C. Curtis, "Transitioning to Transit-Oriented Development: The case of Perth, Western Australia," Urban Policy Res., vol. 30, no. 3, pp. 275-292, 2012, doi: 10.1080/08111146.2012.665364.

[7] A. Nasri and L. Zhang, "The analysis of transit-oriented development (TOD) in Washington, D.C. and Baltimore metropolitan areas," Transp. Policy, vol. 32, pp. 172-179, 2014, doi: 10.1016/j.tranpol.2013.12.009.

[8] P. Phani Kumar, C. Ravi Sekhar, and M. Parida, "Identification of neighborhood typology for potential transit-oriented development," Transp. Res. Part D Transp. Environ., vol. 78, p. 102186, 2020, doi: 10.1016/j.trd.2019.11.015.

[9] A. Ford, Modeling the Environment: An introduction to System Dynamics : Models of Environmental Systems. Washington: Island Press, 1999.

[10] J. D. Sterman, Business Dynamics: System Thinking and Modeling for A Complex World. Boston, Massachusetts: McGraw-Hill, 2000.

[11] R. Ewing and R. Cervero, "Travel and the built environment," $J$ Am. Plan. Assoc., vol. 76, no. 3, pp. 265-294, 2010, doi: 10.1080/01944361003766766.

[12] W. Budiati, A. B. Grigolon, M. J. G. Brussel, and S. Y. Rachmat, "Determining the potential for Transit Oriented Developmen along the MRT Jakarta corridor," in IOP Conference Series: Earth and Environmental Science, 2018, vol. 158, no. 1, p. 12020, doi: 10.1088/1755-1315/158/1/012020.

[13] J. De Vos, V. Van Acker, and F. Witlox, "The influence of attitudes on Transit-Oriented Development: An explorative analysis," Transp. Policy, vol. 35, pp. 326-329, 2014, doi: 10.1016/j.tranpol.2014.04.004.

[14] K. A. Ratner and A. R. Goetz, "The reshaping of land use and urban form in Denver through transit-oriented development," Cities, vol. 30, no. 1, pp. 31-46, 2013, doi: 10.1016/j.cities.2012.08.007.

[15] E. A. Teklemariam and Z. Shen, "Determining transit nodes for potential transit-oriented development: Along the LRT corridor in Addis Ababa, Ethiopia," Front. Archit. Res., vol. 9, no. 3, pp. 606622, 2020, doi: 10.1016/j.foar.2020.03.005.

[16] M. Kamruzzaman, F. M. Shatu, J. Hine, and G. Turrell, "Commuting mode choice in transit oriented development: Disentangling the effects of competitive neighbourhoods, travel attitudes, and self-selection," Transp. Policy, vol. 42, pp. 187-196, 2015, doi: 10.1016/j.tranpol.2015.06.003.

[17] Y. J. Singh, P. Fard, M. Zuidgeest, M. Brussel, and M. van Maarseveen, "Measuring transit oriented development: A spatial multi criteria assessment approach for the City Region Arnhem and Nijmegen," J. Transp. Geogr., vol. 35, pp. 130-143, 2014, doi: 10.1016/j.jtrangeo.2014.01.014.

Y. J. Singh, J. Flacke, M. Zuidgeest, and M. van Maarseveen, "Planning for Transit Oriented Development (TOD) Using a TOD Index," in GIS in Sustainable Urban Planning and Management M. van Maarseveen, J. Martinez, and J. Flacke, Eds. Boca Raton, Florida: CRC Press, 2015.

[19] A. Tahir, "Angkutan massal sebagai alternatif mengatasi persoalan kemacetan lalu-lintas Kota Surabaya," SMARTek, vol. 3, no. 3, pp. 169-182, 2005.

[20] R. Huang, A. Grigolon, M. Madureira, and M. Brussel, "Measuring transit-oriented development (TOD) network complementarity based on tod node typology," J. Transp. Land Use, vol. 11, no. 1, pp. 304-324, 2018, doi: 10.5198/jtlu.2018.1110.

[21] E. Suryani, R. A. Hendrawan, P. F. E. Adipraja, A. Wibisono, and L. P. Dewi, "Urban mobility modeling to reduce traffic congestion in Surabaya: a system dynamics framework," J. Model. Manag., 2020, doi: 10.1108/JM2-03-2019-0055.

[22] J. Pucher, R. Buehler, and M. Seinen, "Bicycling renaissance in North America? An update and re-appraisal of cycling trends and policies," Transp. Res. Part A Policy Pract., vol. 45, no. 6, pp. 451-475, 2011, doi: 10.1016/j.tra.2011.03.001.

[23] C. D. Higgins and P. S. Kanaroglou, "A latent class method for classifying and evaluating the performance of station area transitoriented development in the Toronto region," J. Transp. Geogr. vol. 52, pp. 61-72, 2016, doi: 10.1016/j.jtrangeo.2016.02.012.

[24] K. Manaugh and A. El-Geneidy, "Validating walkability indices: How do different households respond to the walkability of their neighborhood?," Transp. Res. Part D Transp. Environ., vol. 16 no. 4, pp. 309-315, 2011, doi: 10.1016/j.trd.2011.01.009.

[25] W. Rusiawan, P. Tjiptoherijanto, E. Suganda, and L. Darmajanti, "System dynamics modeling for urban economic growth and $\mathrm{CO} 2$ emission: A case study of Jakarta, Indonesia," Procedia Environ. Sci., vol. 28, pp. 330-340, 2015, doi 10.1016/j.proenv.2015.07.042.

[26] S. Sulistyaningrum and J. Sumabrata, "Transit Oriented Development (TOD) index at the current transit nodes in Depok City, Indonesia," in IOP Conference Series: Earth and Environmental Science, 2018, vol. 126, no. 1, doi: 10.1088/17551315/126/1/012217.

[27] Y. Zhang, S. Marshall, and E. Manley, "Network criticality and the node-place-design model: Classifying metro station areas in Greater London," J. Transp. Geogr., vol. 79, p. 102485, 2019, doi: 10.1016/j.jtrangeo.2019.102485.

[28] M. Alim, "Hubungan kondisi lingkungan fisik dengan kemacetan lalu-lintas di Kota Surabaya," Swara Bhumi, vol. 2, no. 1, pp. 178 186,2013

[29] D. Olaru, B. Smith, and J. H. E. Taplin, "Residential location and transit-oriented development in a new rail corridor," Transp. Res. Part A Policy Pract., vol. 45, no. 3, pp. 219-237, 2011, doi: 10.1016/j.tra.2010.12.007.

[30] D. Q. Nguyen-Phuoc, G. Currie, C. De Gruyter, I. Kim, and W. Young, "Modelling the net traffic congestion impact of bus operations in Melbourne," Transp. Res. Part A Policy Pract., vol. 117, pp. 1-12, 2018, doi: 10.1016/j.tra.2018.08.005.

[31] W. B. Fontoura, G. M. Ribeiro, and G. D. L. D. Chaves, “A framework for evaluating the dynamic impacts of the Brazilian Urban Mobility Policy for transportation socioeconomic systems: A case study in Rio de Janeiro," J. Simul., vol. 14, no. 4, pp. 316 331, 2020, doi: 10.1080/17477778.2019.1701392.

[32] H. Haghshenas, M. Vaziri, and A. Gholamialam, "Evaluation of sustainable policy in urban transportation using system dynamics and world cities data: A case study in Isfahan," Cities, vol. 45, pp. 104-115, 2015, doi: 10.1016/j.cities.2014.11.003.

[33] X. Liu, S. Ma, J. Tian, N. Jia, and G. Li, “A system dynamics approach to scenario analysis for urban passenger transport energy consumption and $\mathrm{CO} 2$ emissions: A case study of Beijing," Energy Policy, vol. 85, pp. 253-270, 2015, doi: 10.1016/j.enpol.2015.06.007.

[34] A. Faradibah and E. Suryani, "Pengembangan model simulasi sistem dinamik untuk meningkatkan efisiensi sistem operasional 
The $6^{\text {th }}$ International Seminar on Science and Technology (ISST) 2020

July $25^{\text {th }} 2020$, Institut Teknologi Sepuluh Nopember, Surabaya, Indonesia

transportasi," Ilk. J. Ilm., vol. 11, no. 1, pp. 67-76, 2019, doi: 10.33096/ilkom.v11i1.413.67-76.

[35] A. J. C. Trappey, C. Trappey, C. T. Hsiao, J. J. R. Ou, S. J. Li, and K. W. P. Chen, "An evaluation model for low carbon island policy: The case of Taiwan's green transportation policy," Energy Policy, vol. 45, pp. 510-515, 2012, doi: 10.1016/j.enpol.2012.02.063.

[36] N. L. A. Widyahari and P. N. Indradjati, "The Potential of TransitOriented Development (TOD) and its opportunity in Bandung Metropolitan Area," Procedia Environ. Sci., vol. 28, pp. 474-482, 2015, doi: 10.1016/j.proenv.2015.07.057.

[37] A. Sahu, "A methodology to modify land uses in a transit oriented development scenario," J. Environ. Manage., vol. 213, pp. 467477, 2018, doi: 10.1016/j.jenvman.2017.12.004.

[38] P. Pezeshknejad, S. Monajem, and H. Mozafari, "Evaluating sustainability and land use integration of BRT stations via extended node place model, an application on BRT stations of Tehran," J. Transp. Geogr., vol. 82, p. 102626, 2020, doi: 10.1016/j.jtrangeo.2019.102626.

[39] H. M. Taki and M. M. H. Maatouk, "Promoting transit oriented development typology in the transportation planning," Commun. Sci. Technol., vol. 3, no. 2, pp. 64-70, 2018, doi: 10.21924/cst.3.2.2018.103

[40] K. D. M. E. Handayeni and P. G. Ariastita, "Keberlanjutan transportasi di Kota Surabaya melalui pengembangan kawasan berbasis TOD (Transit Oriented Development)," TATA LOKA, vol.
16, no. 2, pp. 108-115, 2014.

[41] P. Suarez, W. Anderson, V. Mahal, and T. R. Lakshmanan, "Impacts of flooding and climate change on urban transportation: A systemwide performance assessment of the Boston Metro Area," Transp. Res. Part D Transp. Environ., vol. 10, no. 3, pp. 231-244, 2005, doi: 10.1016/j.trd.2005.04.007.

[42] H. Vafa-Arani, S. Jahani, H. Dashti, J. Heydari, and S. Moazen, "A system dynamics modeling for urban air pollution: A case study of Tehran, Iran," Transp. Res. Part D Transp. Environ., vol. 31, pp. 21-36, 2014, doi: 10.1016/j.trd.2014.05.016.

[43] Y. H. Cheng, Y. H. Chang, and I. J. Lu, "Urban transportation energy and carbon dioxide emission reduction strategies," Appl. Energy, vol. 157, pp. 953-973, 2015, doi: 10.1016/j.apenergy.2015.01.126.

[44] Q. I. Ahmed, H. Lu, and S. Ye, "Urban transportation and equity: A case study of Beijing and Karachi," Transp. Res. Part A Policy Pract., vol. 42, no. 1, pp. 125-139, 2008, doi: 10.1016/j.tra.2007.06.004.

[45] B. S. Reddy, "Urban transportation in India: a tale of two cities," Energy Sustain. Dev., vol. 4, no. 1, pp. 65-76, 2000, doi: 10.1016/S0973-0826(08)60232-X.

[46] R. Mu and M. de Jong, "Establishing the conditions for effective transit-oriented development in China: the case of Dalian," $J$. Transp. Geogr., vol. 24, pp. 234-249, 2012, doi: 10.1016/j.jtrangeo.2012.02.010. 